Драган Л. ХАМОВИЋ

Институт за књижевност и уметност Београд
Оригинални научни рад

Примљен: 15. 10. 2016.

Прихваћен: 10. 02. 2017.

\title{
ЈОВАН ХРИСТИЋ КАО ТЕОРЕТИЧАР ЕСЕЈА И АУТОР ЕСЕЈИСТИЧКЕ ПРОЗЕ
}

\begin{abstract}
Жанровска природа есеја и статус есеја у модерном књижевном контексту уочавају се као привилеговане, чак опсесивне теме Јована Христића. Образлаже есејизам као савремену наджанровску чињеницу, која омогућава не само пожељно мешање облика него и спајање „универзалности филозофије и конкретности поезије”. Есејистичка проза, заступљена у збиркама Професор математике и Тераса на два мора представља стваралачки израз Христићевог теоријског испитивања природе есеја.

Кључне речи: Јован Христић, модерни есеј, есејистички стил, есејистичка проза.
\end{abstract}

Пишући наручени есеј о есеју, насловљен „Пропланци есеја”, Сретен Марић - „човек разговора”, како га именује Јован Христић - у форми одговора уреднику темата у часопису Дело реторски пита: „Колико Ви знате студија о есеју, не гледајући у библиографије?” (Марић 1976: 5) - напомињући да он памти само радове Вирџиније Вулф, Адорна, Лукача и Бенсеја. Међутим, освежавајући памћење радовима из домаће средине, Марић је, рецимо, могао поменути да је тачно двадесет година раније на српском језику изашао превод збирке есеја Вирџиније Вулф, с текстом „Модерни есеј”, на који се и позвао - а да је ова објава изазвала есеј „Муке с једним обликом” (1957) Миодрага Павловића. Павловићев текст сигнализује основно проблемско питање у додатку наслова, који гласи „Куда иде есеј?”: „Унутрашња, неформална структура есеја подразумева особену мешавину доживљаја и знања, искуства и умовања. Он је узбудљив пресек наше душевне истовремености" (Павловић 1958: 115) - исписује српски песник, не мање чувен као есејиста. Треба нагласити да је есеј Вулфове (о вековној баштини енглеског есеја) Павловићу послужио као повод за промишљање актуелних облика старог књижевног облика. Павловића не занимају само константе у променљивом

\footnotetext{
"hamovicdragan@gmail.com
} 
трајању есеја него у први план поставља увид о посебном статусу есеја у епохалном часу модерности из којег се оглашава:

Која је то сила што у општој размени идеја, у превратима разних дисциплина, задржава овај облик не само на окупу него и у снази? Чини се да је та сила баш у наше време разголићенија него раније. То је кохезија облика који све вари а остаје сам себи сличан (Исто: 114).

Павловић отпочиње нову знатну тему послератне српске књижевне модерности, јер му се у исто време, текстом „Анатомија есеја”, придружује и Јован Христић са блиско постављене аналитичке тачке. Христићу се ова тема отвара као опсесивна лична тема, стваралачка колико и теоријска, које се неће остављати и коју ће потанко развијати читаву наредну, ауторски продуктивну деценију. Христић начиње да решава „проблем есеја” у осврту на два изабрана есејистичка догађаја, на појаву Камијевог Лета и Анине балске хаљине Душана Матића. И Христић, попут Павловића, испитује шта се то наочиглед свих мења у лику есеја каквог је засновао Монтењ, с краја 16. века. Припрему закључка који следи, поводом есеја у модерном интелектуалном контексту, Христић прибавља позивајући се на Камијево становиште „како треба превазићи нихилизам и открити једну нову наду" - напомињући да то не би био хуманизам 15. или 16. века, него хуманизам „тоталне личности” (Христић 1957: 103-104). Христић оличење такве тоталности налази у лику Демокрита, односно у предсократовским мислиоцима, што је повесни простор којем ће се радо враћати. Описане тежње општег духовног карактера Јован Христић пресликава на опис природе есеја као „трилеме између живота, литературе и филозофије", али не као колебања између њих, него схватања „ова три члана у њиховом тоталитету”, „њихове суштинске нераздвојности и нераздвојивости" (Исто: 107). Говорећи најпре о есеју као текстовном склопу, Христић истовремено указује на есејизам као епохални процес, о чему ће опширније писати, као очито привилегованој теми, у књизи Облици модерне къижевности (1968). У поглављу „Судбина есеја” ове књиге иде и корак даље, те обазриво уводи тврдњу да је „есеј постао карактеристична стилска одлика модерне књижевности, облик садржан у свим њеним облицима" (Христић 1968: 155).

Уосталом, сваки пут кад говори о есеју, Христић уједно образлаже есејизам као савремену наджанровску чињеницу. У насловном тексту збирке есеја Поезија и филозофија (1964) посреди је, у основи, исто разматрање, с том разликом што је у фокусу питање односа између дискурзивних и сликовитих елемената модерне књижевности, у чему Христић види „настанак једног новог (или можда обнову једног старог) сензибилитета који у себи спаја универзалност филозофије и конкретност поезије" (Христић 1964: 10). Овом приликом, есеј само није директно именован као одговарајући облик изражавања такве осећајности. У есејистичком стилу - како га одређује аутор Облика модерне књижевности - изнова налазимо ону „природну стопљеност филозофске уопштености и песничке конкретности” (Христић 1968: 155), што су ставке које аутор понавља или варира и у цитираном уводу есеја 
„Поезија и филозофија”, али и у разматрању књижевности Душана Матића у раном раду „Анатомија есеја” (Поезија и критика поезије, 1957), те у текстовима одељка о Матићу у Поезији и филозофији: „За мене, Матићева поезија је филозофија која тек песничком сликом постаје конкретна, и поезија која се тек филозофијом ослобађа свега сувишног" (Христић 1962: 104). Христићев опис Матићеве поезије једнако вреди и за Матићеву есејистику, тумач нема потребу да одваја текстове иначе жанровски мешовите. Христићу је Матићев песнички случај био огледни пример, полазиште и за сопствену жанровски хибридну стратегију, за коју се залагао као песник, а не као одмакнути теоретичар. Отуда се питање песник или есејист, у тадашњој критици постављено поводом Христића, и не може узети као ваљано, јер Матићев случај - на који се Христић наслања - сугерише одговор да ту дихотомије нема, макар не унутар поставангардних поетика. Такав двојни импулс код Христића запажа још Борислав Михајловић у оцени Дневника о Улису, говорећи да је реч о песнику за кога је уверен да ће постати добар есејиста, али који ће дуго песнички тражити себе. И уистину, тражио је дуго и објашњавао нађено, себи и другима. Не треба заборавити на резервисан почетни пријем песника Христића код дела критике, не само на примеру друге збирке, Песме 1952-1956 (1959), него чак и Александријске школе (1963), данас малтене канонизоване, јер се местимице нескривено постављала дилема песник или есејист, тј. вредносна недоумица поводом песничког аутора кога, опет, нико није озбиљно могао оспорити као есејисту. Очевидно, у формативном периоду Јована Христића - и у декларативном слоју есеја колико у интертекстуалним одјецима песама - као парадигма се појављује књижевна фигура Душана Матића, који укида границе између различитих облика певања и мишљења. Обојица су песници-есејисти, с тим што је Христић пуну критичку оверу морао мало да причека.

Пишући о Сретену Марићу као есејисти, Христић прави одсечну разлику између два приступа: „Научници се баве чињеницама, есејисти вредностима" (Христић 2005: 137). У текстовима прве есејистичке збирке, Поезија и критика поезије, Христић јасно оцртава теоријску подлогу свог песничког концепта у настајању, оптирајући за тип песника-критичара уместо критичара-научника. Погледом сеже до антике, како смо приметили, истичући помињани идеал „тоталне личности”, запажајући да се „данас то осећање интегралности губи", а улогу коју додељује есеју представља изналажење „најдубљег самоосећања себе у односу према животу”. Када, опет, у књизи Поезија и филозофија, поводом Стеријине поезије, помиње стоицизам, нагласак описа овог античког мудрачког правца сасвим је саображен раније израженом одређењу есеја и модерног есејизма - скоро да можемо међусобно заменити формулације о стоицизму и есејизму, јер су малтене истоветне. Стоици, наиме, према Христићу, показују „како истине откривене у разним областима људског искуства и знања прожимају све области нашег искуства" (Исто: 60), а есеј, не само у Христићевом виђењу, по својој природи, такође размиче условне међе између разних искустава и дисциплина. На трагу овакве поставке налази се и доцнији увид Михаила Епштејна, тумача који такође посматра есеј као културну појаву модерног доба, на начин упоредив 
с Христићевим, који смо сажето предочили: „есејистика узима на себе, у новом времену, ту функцију обједињавања, консолидације различитих области културе" (Епштејн 1997: 31-32). Епштејн, као и Христић, излаже епохални проблем изостанка сазнајне целовитости и есеју такође приписује „функцију целовитости, посредног изражавања философског, уметничког и историјског, или мисли, слике и бића; али, то се остварује управо у духу новог времена, коме је целовитост доступна једино у искуству досезања до ње, у покретноколебљивој равнотежи саставних делова" (Исто: 42).

Како се успоставља целовитост есејистичког умног трагања? Према Адорновом писању, „пустоловно-дисконтинуирани, импровизовани есеј добија свој континуитет личношћу и језиком аутора” (Адорно 1996: 62). Индивидуалност аутора излази у први план, динамика „сопствене парадоксалне егзистенције", као у лику оне симболичне фигуре за којом Христић посеже још у уводу Облика модерне књижсевности, фигуре Монтења, чијим Есејимa „први пут у историји књижевности један усамљени човек обраћа се исто тако усамљеном читаоцу” (Христић 1968: 37). Назиремо ли у овој стилизованој фигури родоначелника есеја исти онај лик што проговара из своје осаме у збирци Дневник о Улису или њеном наставку, збирци Песме 1952-1956. Другим речима, у ситуацији у којој настаје нововековни облик есеја, пресликава се и типска ситуација модерног песника, какву је оцртао и Христић на својим лирским почецима: камерна самоћа и покушај обраћања недосежном другоме.

Тако се ствара, како наводи Христић, нов облик заједништва, на обредним почецима успостављан кроз ритам. У таквој конфигурацији он види зачетак опште модерне књижевне ситуације, разговорне, непосредне релације писац-читалац, чије је жанровско отеловљење управо есеј. Темељне одлике модерне поетике истородне су одликама есеја: мешање облика, фрагментарност, колоквијалност тона, корелација дискурзивног, наративног и лирског чиниоца. Христић је - понављамо наш став раније формулисан (в. Хамовић 2008: 85-89) - своје есејистичко-теоријске радове, окупљене у три књиге од краја педесетих до краја шездесетих, обликовао као експлицитно поетичке исказе, с позиције песника који афирмише нов, условно речено, неокласични смер модерне српске поезије, чија је призната традиција била оличена у романтизму. Сви су примери из културног наслеђа овде у функцији поетичке замисли која се реализовала у песмама истога периода. Отуда и полемички заоштрени, свакако циљано прејако дати судови, у којима Христић, примерице на рачун Његошеве поезије, афирмише Стеријину рефлексивност и дубину, истиче учене српске класицисте у односу на наводну „невештину” романтичара. Тиме је, понављамо, легитимисао традицијску линију дотад истиснуту главним током књижевног развоја, линију с којом хвата прикључак. Слично је и са поетичким профилом и жанровским облицима што их је теоријски преиспитивао у име личног песничког формирања. Христић je, понављамо, посвећивао Матићу знатну есејистичку пажњу, с тим што је већина тих текстова претежно лирска, тек мањином дискурзивна, текстови су жанровски неодређени. Тако је програмско-поетичког карактера и следећа 
Христићева генерализација, изнета у Облищима модерне књижевности, да „права особеност модерне уметности није у хипотетичкој чистоти облика, већ у својеврсном мешању облика" (Христић 1968: 53). Када нешто даље оглашава фрагмент за једину могућу аутентичну модерну форму, у томе је садржана свест о фрагментарности као подразумеваној црти есеја, јер је есеј - као што примећује Адорно - „формално тако слабо ограђен да прелази у фрагмент”, додајући да есеј од фрагмента разликује само језик, више говорни него писани, „компонован као говор, приповетка или дијалог, уређен по музичким законима" (1996: 62). Колоквијалност језика је међу првим Христићевим поетичким својствима.

Књижевноисторијски или театролошки есеји Христићеви сачињавају један низ, док текстови окупљени у збиркама Професор математике (1988, допуњено 1997) и Тераса на два мора (2002) чине други, одељен корпус (в. о томе Хамовић 2008: 121-152). С једне стране, могу се ови текстови читати као екстензивни коментари што дозивају Христићеве тематске преокупације и подтексте у песмама - те основано призвати асоцијације на жанровски мешовите позне збирке Матића, Дединца или Црњанског - али се могу читати и као примери његовог схватања модерне песничке форме, вишекратно исказиваног у теоријски интонираним есејима. (Уосталом, и сам аутор је, у једном интервјуу, напоменуо да је ове есејистичке текстове писао као песме, кришом.) Отуда и ауторово колебање у именовању две жанровски истоврсне књиге. Професор математике носи одређење „и други есеји”, док је Тераса на два мора понела поднаслов „и друге истините приче”. У другом књижевном разговору, Христић изнова објашњава променљиву природу есеја, дајући кључ и за поменуте „есејистичке приче”. Наглашава притом две кључне околности, доколииу и приповедање: „Есеј приповеда о неким збивањима у животу и покушава да их сажме у какву-такву поруку; приповеда о ономе што је писцу прошло кроз главу; приповеда о ономе што је есејист прочитао” - и онда поентира: „Кад изгуби везу са приповедном прозом, он се сасуши у академску расправу" (Зубановић, Пантић 1992: 109). Зато Христић појачава везу својих позних, књижевно особитих и семантички прозрачних есеја са приповедном прозом, чији је суздржани лиризам остао дубински тон главнине ових текстова. Ове прозе прате тенденцију ауторског одустанка од ерудитне тематике те обраћања неизбрисивим чињеницама живота „сачињеног од ситница”, а тај смер обележава завршни период његове поезије.

Христић је, тако гледано, еволуирао од заступника херојског доба модернизма у класично засведеног писца, који се опире мутним бесмислицама толерисаним у име слободе и бескрајних опита у изразу. А есеј је, према Адорну, играње слободом, „покушај да се допре до ивице њених искушења - и да се не подлегне" (1996: 64). Христићева озбиљност и мера није допустила да подлегне тим искушењима, чему је особити досег његова есејистика, у свим варијететима којима је прибегавао. Закључак Михаила Епштејна који следи блиско кореспондира с битним моментима позиције коју је, неку деценију пре Епштејна, наш песник и есејиста заступао, опредељујући се за повратак изворнијим основама савремене уметности: 
Попут митологије у древним културама, есејизам врши мисију повезивања, али на основу најдрагоценијег открића новог времена - вредности издвојене човекове личности, коју је потврдила ренесанса. Есејизам је синтеза разноврсних форми културе на основу самосвести личности, која води, захваљујући том посредовању, до све виших нивоа духовне универзалности [...] Његова сврха је подржавање равнотеже у систему, остваривање везе између свих периферних издвојености, најдаљих и најпрецизнијих специјализација са централном свешћу личности - а не затварање система. Иначе би за очување целовитости културе морала бити жртвована њена основна вредност и смисао - отвореност (Епштејн 1997: 66).

Мислимо да би овакав закључак Христић дословце потписао. Заправо, Христић је, независно од наведене Епштејнове синтезе, развио истосмерне поставке - да би их потврдио текстовима есејистичке прозе, изнутра, што је најпотпунија потврда сваког искуства. Није се либио да на самом крају своје кровне теоријско-поетичке књиге - у којој је есеј ако не „главни јунак” оно „издвојени лик” - искаже далекосежни закључак: „Верујем да је есејистички стил у модерној књижевности једини успео да очува равнотежу између експлицитног и имплицитног, облика и изјаве, којом књижевност доказује своју важност и своју виталност [...] Наш живот је тражење логоса, и логоса се можемо држати ако нам је стало да преживимо" (Христић 1968: 166). У такву је личну потрагу Јован Христић био упрегао сва доступна оруђа певања и мишљења, у сложеном искуственом садејству, што се најпотпуније изражавало кроз облик који оквирно називамо есејем, облик „који све вари а остаје самом себи сличан” и „спаја универзалност филозофије и конкретност поезије".

\section{ЛИТЕРАТУРА И ИЗВОРИ}

Адорно 1996: Т. Адорно, Есеј о есеју, Реч, год. 3, бр. 18, фебруар, Београд, 61-63.

Епштејн 1997: М. Епштејн, Есеј, Београд: Народна књига - Алфа.

Зубановић, Пантић 1992: С. Зубановић, М. Пантић, Десет песника, десет разговора, Нови Сад: Матица српска.

Марић 1976: С. Марић, Пропланци есеја, Дело, год. 22, књ. 22, бр. 5, Београд, $1-17$.

Павловић 1958: М. Павловић, Рокови поезије, Београд: Српска књижевна задруга.

Хамовић 2008: Д. Хамовић, Лето и цุитати, Поезија и поетика Јована Христића. Београд: Завод за уџбенике.

Христић 1957: Ј. Христић, Поезија и критика поезије, Нови Сад: Матица српска.

Христић 1964: Ј. Христић, Поезија и филозофија, Нови Сад: Матица српска.

Христић 1968: Ј. Христић, Облици модерне књижевности, Београд: Нолит.

Христић 2005: Ј. Христић, Изабрани есеји, Београд: Српски Пен центар. 
Dragan L. Hamović

\title{
JOVAN HRISTIĆ AS THEORETICIAN OF ESSAY AND AS AUTHOR OF ESSAYISTIC PROSE
}

\begin{abstract}
(Summary)
Essay is the privileged, even obsessive theme of Jovan Hristić. His essay literature, by which he first gained his literary reputation, was from the beginning (1950s and 1960s) in function of promoting neoclassical poetic model which he (along with the leading authors of his modernist generation) supported in poetry, primarily through reaffirmation of, until then, marginalized precursors of the classical direction from the Serbian poetry of the $19^{\text {th }}$ century. By favouring essay and essayistic style in the context of the modern theories of poetry, Hristic writes essayistic lyrical prose, founded on the obsessive themes from his poetry, which can be taken as a specific creative application of the mentioned theoretical ideas. According to the view of Jovan Hristić, essay represent integrative literary form of modern age, which contains "philosophical universality and concreteness of poetry".
\end{abstract}

